$\begin{array}{r}\text { Volume and Issues Obtainable at Center for Sustainability Research and Consultancy } \\ \text { Journal of Accounting and Finance in Emerging Economies } \\ \text { ISSN: 2519-0318 ISSN (E) 2518-8488 } \\ \text { Volume 3: Issue 2 December 2017 } \\ \text { JSRᄃ } \\ \text { Journal homepage: } \text { www.publishing.globalcsrc.org/jafee } \\ \hline\end{array}$

\title{
Empirical Study of the Relationship between Board of Director Mechanisms and Perceived Performance of Listed Firms in Nigeria
}

\author{
${ }^{1}$ Mohammed Nuhu, ${ }^{2}$ Suleiman Muhammad Hussani \\ ${ }^{1}$ School of Business Management, Universiti Utara Malaysia, Malaysia.mohammed.nuhu12@yahoo.com \\ 2Department of Business Administration, Ahmadu Bello University, Zaria, Nigeria
}

\begin{abstract}
ARTICLEDETAILS
History

Revised format: Nov 2017

Available online: Dec 2017

Keywords

Board Composition,

Responsibility,

Accountability and Firm

Performance

JEL Classification:

J28, D21

ABSTRACT

Purpose:The growing debate on the board of director mechanisms to firm performance will for a long time remain area of research. The effectiveness of the board of director composition, responsibility, and accountability have become an area of research in the recent trend. This paper attempts to investigate the empirical study of the relationship between the board of director mechanisms and perceived performance of listed firms in Nigeria. The underpinning theory of the paper is rooted in agency theory and supported by resource dependence theory, and stewardship theory to increase the understanding of the influence of the board of director formation to perceived firm performance. The questionnaires were administered to the respondents, out of 182 questionnaires administered, 117 were returned. The number of valid questionnaires is 114. The data were analyzed using Partial Least Squares Structural Equation Modeling (PLS-SEM). Empirical findings showed that board of director composition and accountability were positively associated with perceived firm performance. While the board of director responsibility has no relationship. Based on the knowledge of this paper, this is the first study that adopts the use of primary data to investigate the empirical study of the relationship between the board of director mechanisms and perceived performance of listed firms in Nigeria. The findings provide policymakers, stakeholders, and government with the approaches to overcome and resolved the conflict of interest between the board of director (agent) and shareholder (principal). The paper also offers some suggestions for future study.
\end{abstract}

(C) 2017 The authors, under a Creative Commons AttributionNonCommercial 4.0

Corresponding author's email address: mohammed.nuhu12@yahoo.com

Recommended citation:Nuhu, M. \&Hussani, S.M., (2017).Empirical Study of the Relationship between Board of Director Mechanisms and Perceived Performance of Listed Firms in Nigeria.Journal of Accounting and Finance in Emerging Economies, 3(2) 159-178.DOI:https://doi.org/10.26710/jafee.v3i2.59

\section{Introduction}

The recent debate on the performance of insurance firm will for a long time remain an area of interesting research. The scandals in the early 1990's has exposed many multinational firms in the United Kingdom and United States with a high-profile corporate scandals, unexpected corporate failures, unprofessional behaviours by the Chief Executive Officer (CEO) and management (Adegbite, 2015; Al-matari, 2014; Ehikioya, 2009; Harvey Pamburai, Chamisa, Abdulla \& Smith, 2015; Rossi, Nerico\&Capasso, 2015; Nuhu\& Ahmad, 2017; Samaduzzaman, Zaman \&Quazi, 2015). It has been suggested that the scandals at 
Enron, WorldCom, Qwest, Tyco and other corporate entities in the US resulted in a loss of more than USD 7 trillion of investors' funds (Donaldson, 2003; Global Issue, 2009; Lawal, 2012). The estimated value of the Lehman Brothers scandals and other giant corporate entities stood at USD 14.5 trillion (Global Issue, 2009; Lawal, 2012).

The manipulation of financial statement by many listed firms in Nigeria has created a bottleneck between the manager (agent) and the owners (principal). This has to lead to the collapsed of notable leading high profile listed firms and others financial institutions in Nigeria such as Finbank, Bank PHB, Bank of the North, Afribank, Oceanic Bank and Intercontinental Bank among others. This is as a results of lack of Corporate Governance (CG) practices, corruptions in the system, reckless loan provision, loans given to family member without paying back, bad debt, unethical banking practices, including the inflation of revenue, the distortion and manipulation of financial statement, diversion of bank funds and granting of unsecured credit facilities without proper authorization were is still found operating in the insurance firm and others financial services in Nigeria (Central Bank of Nigeria 2011; Sanusi, 2012). This was the time when the market capitalization of Nigeria dropped significantly from N12 trillion to N9 trillion (Adamu, 2009).

Consequences, prior studies contended that the collapse of major corporate institutions in both developed and developing economies are attributed to lack of corporate governance practice that found many institutions with guilty of financial manipulation and distortion of funds (Avgouleas, 2008; Lawal, 2016Adamu, 2009). In modern practice, managers often pursued their interest rather than the interest of their owners (Berle\& Means, 1932; Lawal, 2012). The above school of thought argued that every successful firmneeds to put in place a mechanism that will help in resolving agency problem or conflict of interest that exist between the shareholders and managers. While other study contended that the size of the board of directors is seen as the most paramount important in corporate governance mechanism (Fama\& Jensen, 1983; Hermalin\&Weisbach, 2003; Johl et al, 2015). Hence, each shareholder wants their representation on the board of directors of every firm especial in the Nigeria setting or context due to a conflict of interest between the owner and the manager (Nuhu\& Ahmad, 2016). The research on the issue of agency problems between manager and shareholder (principal and agent) will for a long time remain a topic of debate. Therefore, the issue of count head or a number of peoples or directors on the board might be new but the issues and challenges it addresses are not (Ayuso\&Argandona, 2007; Lawal, 2016; Lawal, 2012).

The objectives of this paperare to investigate the relationship between the board of director mechanisms and the perceived performance of listed firms in Nigeria with the view of the new focus of methodological approach and underpinning theory. This paper is divided into; introduction, literature reviews, methodology, results, discussion, conclusion, and recommendations for future research.

\section{Literature Reviews}

\subsubsection{Corporate Governance and Firm Performance}

The word,Governance is a term derived from Greek-Latin word gubernare, which translates as the act of steering that was first used in a metaphorical by Plato. The steering is an institution of the state through the creation of enabling conditions for the enforcement of the rule of law and collective decision making (Rampersad\& Hussain, 2014; Robichau, 2011; Solomon, 2007). Initially, governance was synonymous with the management of political/social units, specifically government institutions. This notion has now transcended from the state focus into a market-based application with emphasis on the management of corporations, also known as corporate governance (Offe, 2009). The introduction of governance in the management of corporations was designed to mitigate unethical practices through the promotion of corporate transparency and accountability (Cadbury, 2000). Corporate governance had been defined in 
many ways by different researchers, authors, institutions, industries, etc. The concept of corporate governance itself has undergone a series of transformations.

Corporate governance is a concept that represents the entire system by which companies are directed and controlled by a board (Cadbury Report, 1992). Therefore, in finance and management terminology, corporate governance is to solve what is called the problem of the agency which exists between stockholders or shareholders and managers. Therefore, that is what corporate governance is intended to resolve in making sure investors get their investment back, given that somebody else (managers or agents) will make ensure that all the decisions making process about how their investment or their money have utilized (Akinkoye\&Olasanmi, 2014; Lawal, 2012; Lawal, 2016). Good Corporate Governance promotes the efficient and effective use of the capital within the company or firms and their return on their capital or resources (Tai, 2015). Corporate governance mechanisms have been identifying as method or techniques used in determining the success and outcome of every firm performance (Adjaoud et al, 2007; Clarke, 2007; Guerra et al, 2009; Lawal, 2016). Hence, this section reviews the prior relationship between the following; corporate transparency and accountability and firm performance; corporate behavior and firm performance and shareholder rights and firm performance.

\subsubsection{Board of Director and Firm Performance}

The board of directors, as an internal monitoring mechanism, is designed in line with the agency doctrine to oversee how the executive team manages the firm in the absence of direct participation from the shareholders (Adjaoudet al., 2007; Heracleous, 2001). The introduction of the board as part of a firm's governance equation is aimed at ensuring accountability and reducing the moral hazard associated with the delegation of authority. Shareholders relinquish some of their decision-making rights to the constituted board that is now responsible for making strategic choices in a way that protects the interests of the owners as well as possible (Molz, 2007). Bozec (2005), contended that the board of directors became a necessary variable in a firm's governance calculation because of the need to address the fundamental problem of corporate entities, the significant diffusion of ownership.

Many debates on corporate governance, in both academia and practice, have focused on the board of directors (Berghe\&Levrau, 2004). Often regarded as the most significant constituency in firm governance, the corporate board plays an intermediary role that links the firm and its owners with those who provide professional management and other ancillary support services (Bozec, 2005; Chen et al., 2009). The board of directors shoulders the majority of a firm's management tasks (Filatotchev \& Boyd, 2009). Apart from being saddled with the responsibility of stopping executive extremes, the board is the final or ultimate decision-making body through which the fate of the corporation is discussed and determined (Adjaoudet al., 2007; Fama\& Jensen, 1983; Yawson, 2006).

Because of the renewed focus on the internal governance of corporations, discussion on corporate governance has shifted to the functions of the board of directors (Heracleous, 2001; Jonsson, 2005; Ness et al., 2010; Stiles, 2001). The corporate board, as an internal mechanism, is expected to have a predetermined sense of purpose with clearly defined roles that facilitate the directors' effectiveness in carrying out their fiduciary responsibilities. Nicholson \& Kiel (2004), argued that the role of the board varies across industries and countries and that a detailed understanding of these roles is critical in empirical studies on board structure. They observed that irrespective of the divergences, there are some key determinants of the ultimate role that the board of directors plays in the firm's governance. These factors include the institutional setting and the cognitive capabilities of the board members, as well as the degree of interference, are some of the essential determinants that shape the specific role of the corporate board (Nicholson \& Kiel, 2004).

Therefore, corporate governance encompasses every aspect of running a corporate entity, which amongst 
other things includes the use of both internal board and external board mechanisms (Denis \& McConnell, 2003; Lawal, 2012; Solomon, 2007). The use of internal mechanisms represented by the board of directors stands out. Today, any discussion of corporate governance without the incorporation of the board of directors would seem out of place (Nordberg, 2011). Board of directors is considered as the main internal mechanism of $\mathrm{CG}$ which is designed to control management for dishonest behaviour tendency (Heracleous, 2001; Guan et al, 2007; Johl et al, 2015). Therefore, this paper review three of the board of director mechanisms (Board of Director Composition, Board of Director Responsibility and Board of Director Accountability)

\subsubsection{Board of Director Composition and Firm Performance}

In this paper, the board of director composition reflects the type of board membership (i.e. inside and outside director). Insider directors refer top management team or member that is employees of the firms or its subsidiaries. While Outside directors are grouped of director that are affiliated or non-affiliated (independent) in the company. Hence, affiliated directors are not members of the top management neither employees of the firm but have close links or relationship with the firm, as in the case of retired or former directors, executives or consultants. While non-affiliated directors are 'independent' directors that are recruited to protect the interest of the shareholders. In theory, these non-affiliated or independent directors are not in any way under the control of the firm's executives.

The ongoing debate on the board composition in recent research had shown how important it has influences board of directors, quality deliberation and decisions making process (Ahmadi \&Bouri 2017; Lawal, 2016; Ngulumbu\&Aduda 2016; Pearce \& Zahra 1992; Rosenstein, 1987; Tashakori\&Boulton, 1985). Hence, the composition of the board has demonstrated the ability of the board of directors to exercise their controls over top management to avoid and protect shareholders' interests (Ahmadi \&Bouri 2017; Lawal, 2016; Ngulumbu\&Aduda 2016; Pearce \& Zahra 1992). Again, board composition has impacts on the directors' ability to offer and provide strategic direction that will influence firm performance (Pearce \& Zahra 1992; Baysinger\&Hoskisson, 1990; Nuhu\& Ahmad, 2016).

In the recent stream of research, board composition has been the topic and the subject of extensive investigation as a mechanism or determinant of the performance of a company, although, little is known and aware about the factors that influence and shape board composition (Ahmadi \&Bouri 2017; Hermalin and Weisbach, 1988; Lawal, 2016; Nuhu\& Ahmad, 2016; Ngulumbu\&Aduda 2016; Pearce \& Zahra 1992). Hence, there is a notable tradition of conceptual and research debate going on that boards of directors' composition can influence performance and variety of organizational outcomes (Ahmadi \&Bouri 2017; Ngulumbu\&Aduda 2016; Pearce \& Zahra 1992). This attention has continued to be surface in the academic literature debate (Lawal, 2016; Ngulumbu\&Aduda 2016; Dalton, Daily, Ellstranda\& Johnson, 1998)

Therefore, the rationale for any anticipated direction of the relationships between the board of director composition and firm performance will for a long time remain area of study. Hence, the previous scholars have distinguished that board of director reform activists has argued that any board of directors' should comprise predominantly, independent directors (Dalton et al., 1998; Ngulumbu\&Aduda 2016; Pearce \& Zahra 1992). Thus, many academic scholars have supported the same thought, but this paper hasprovided some alternative perspective in line with the current realities and debate (Ahmadi \&Bouri 2017; Lawal, 2016; Nuhu\& Ahmad, 2016; Ngulumbu\&Aduda 2016). However, the debate in the conceptual literature on the proportion of inside and outside directors on the board of director composition has become a topic of argument (Lawal, 2016; Nuhu\& Ahmad, 2016; Zahra and Pearce, 1989).

A favorite for dominate of the independent (non-executive) boards is supported by agency theory. The 
agency theory believes on the notion that separation of ownership and control, have encouraged selfinterested actions by the managers (control) (Eisenhardt, 1989; Jensen \&Meckling, 1976, Zahra and Pearce, 1989). Agency theory argued that managers or agent are by virtue, have the company knowledge and expertise, that believed to have gained an advantage over company owners (principal) who did not partake from the operational aspects of the company (Mizruchi, 1988). Hence, Agency theory contended that as managers or agent gain control in the company, they are in a better position to pursue interests rather than the interest of the firm owners (Lawal, 2016; Nuhu\& Ahmad, 2016). However, the possible conflict of interest between owner and agent have necessitated debate on the monitoring mechanisms that will protect shareholders or owners of the company (Ahmadi \&Bouri 2017; Fama\& Jensen, 1983; Jensen \&Meckling, 1976; Williamson, 1985). Thus, agency theory believed that effective board of directors should comprise of outside directors. The theory argued that independent (non-executive) directors mostly provide more and superior performance benefits to the shareholders and firm because of their independence from a firm insider or top management.

Some empirical studies have supported agency theory position. Jizi (2017) have found outside or independent directors have positively associated with CSR disclosure among a sample of FTSE 350 firms for the period of 6 years in Lebanon. Ngulumbu and Aduda (2016) found that company with more independent or outside board are more reliable and satisfactory. Ahmadi and Bouri (2017) study the relationship between boards of directors' composition and performance in French CAC 40 listed firms. The found evidence that board composition is positively correlated to the firm' performance. Many other researchers or studies have registered a positive relationship between outside director and firm performance (Abdullah, Ismail \& Jamaluddin 2008; Dal Vesco\&Beuren 2016; Pearce \& Zahra, 1992; Prencipe, 2016; Rosenstein \& Wyatt, 1990; Vafeas and Vlittis, 2016).

In another stream of theory, stewardship theory contended that managers or agent are inherently trustworthy, honest, commitment and are not found in the habit to misappropriate and mismanaged corporate resources (Donaldson \& Davis, 1994; Lawal, 2016; Nuhu\& Ahmad, 2016)). Hence, contended by Donaldson and Davis (1994 p.159) that stewardship theory has argued and supported that managers or agent are good stewards that work diligently to attain the objective of the company. However, this is quite opposite side of the agency theory. Thus, stewardship theory has suggested that the full control of the firm should be centralized in the hands of managers or agents (Davis, Schoorman\& Donaldson, 1997).

Consistent with stewardship theory, some researchers have found that inside directors were associated with higher firm performance. Rasmussen, Ladegård, and Korhonen-Sande (2016) found the positive influence of inside directors and company performance using survey data from 773 high-growth Norwegian firms by adopting ordinary least squares (OLS) regression method. Ganguli and Guha Deb (2016) found a positive relationship with inside director and firm performance. Kesner (1987) have also found a positive relationship between inside directors and returns to investors. However, there is another stream of research that has found no relationship at all between board composition and firm performance (Daily and Dalton, 1992; Galbreath, 2016; Ismail, Ahmad, \&Shaffee, 2016).

Hence, this overview has shown that there is little consistency in the research findings for the board of director composition and firm performance. However, the prior empirical research which has investigated the board composition and financial performance haveignored different methodological approach. Therefore, given the continuing research interest and empirical studies toward the conflicting argument on the relationship between board of director composition and firm performance, this paper, therefore, develop the following hypothesis;

\section{Hypothesis 1:}

There is a significant positive relationship between the board of director composition and the 


\section{performance of insurance listed firms in Nigeria.}

\subsubsection{Board of Director Responsibility and Firm Performance}

The board of director main primary responsibility is to monitor top management on behalf of the owner or shareholders. Board of director responsibility is defined as the duties, role, functions, and activities in which directors carry out on behalf of stakeholders or owners. Hence, one of the primary and major responsibilities any board of directors is it public or private sector is to serve as a monitoring function (frame 1980; Fleischer, Hazard \&Klipper, 1988). Boards of directors play an important key responsibility in corporate governance structures (Guerrero, Lapalme, Herrbach\&Séguin, 2017). The board is entrusted or trusted with a diversity of complementary role, tasks and duties that make the director's responsibility more unique and complex in nature (Guerrero et al., 2017; Nuhu\& Ahmad, 2016).

Huse et al. (2011) contended that board members' identification of their responsibility is important in determining the process, direction and extent to which the monitoring function and monitoring behavior will be actualized. Hence, the board of directors is generally seen as a body that is responsible for ensuring adequate satisfaction of their different stakeholders' demands (Fuente, García-Sánchez, \& Lozano, 2017; Gray et al., 1995; Prado-Lorenzo \&García-Sánchez, 2010; Frías-Aceituno et al., 2012). The importance of every board of director's contribution to firm progress and success have for a long time been at the round table and center of the debate (Mullins \&Schoar, 2016). A very number of recent research has demonstrated that board of director responsibility is the key determinant factor that shown how firms are being managed and perform (Bertrand \&Schoar, 2003; Bennedsen, Neilsen, PérezGonzález \&Wolfenzon 2007; Bandiera, Prat \&Sadun, 2013; Mullins \&Schoar, 2016).

Some recent literature has pointed out the other important aspect of the directorfunctions for effective duties which is seen as a service/collaboration functions (Castro, Galán\&Casanueva, 2016; He et al. 2010). The stewardship theory has argued and challenges the logical that supported agency theory, that the responsibility of the board of director members do not collide with that of owner interest (Castro et al., 2016; Muth\& Donaldson 1998). Hence, the responsibility and role of any board are to assess, control and participate in the day to day strategic decisions making of the firm. Various recent studies have debated the relationship between director role and organizational performance in the literature (Castro et al., 2016; Heracleous 2001; Mullins \&Schoar, 2016; Nuhu\& Ahmad, 2016). Therefore, the impact of the boards of director responsibility in the performance of any firm is it private or public liability can occur or happen, either through the attributes of the board itself or through the functions or responsibility that it performs (Castro et al., 2016; Zahra \& Pearce, 1989). However, in view of the roles, responsibilities or functions, boards performed, some recent researchers have argued out that the board commitment and they are active in the decision making will influence and impact directly on firm performance (Castro et al., 2016; Heracleous 2001; Mullins \&Schoar, 2016; Nuhu\& Ahmad, 2016; Ruigroket al., 2006).

Therefore, the responsibility of the board of directors is one of the numerous institutions that have advanced and developed in recent modem corporations in order to resolve the agency conflict between management responsibility and the interest of the shareholders. But yet, the board of director effectiveness in fulfilling their responsibility is not clear. Thus, some researchers believe the board of directors generally fail in their role and responsibility to monitor top management due to collide of board and management against the interest of the company (American Law Institute, 1982; Dunn 1987; Guerrero et al., 2017; Hermalin\&Weisbach, 1991; Mullins \&Scholar, 2016). Others stream of research, however, argues that company reputation will lead and make the board of directors fulfill their responsibility, duty, and role (Fama 1980; Fama\& Jensen 1983; Lawal, 2016; Nuhu\& Ahmad, 2016).

However, another empirical study (Melkumov et al., 2015) did not in any way yield conclusive results, 
which observed the direct significant relationship between shareholder identification and board monitoring behavior tasks. One of the main reason for this result may be that the link between the director's identification with stakeholders and the monitoring is not a direct and linear but suggested by Huse et al. (2011, p.12), that concentrated on the identification positions of director's involvement in some specific roles. Hence, given the conflicting argument and philosophy of the board of director responsibility and role to company performance, this paper, develop the following hypothesis;

\section{Hypothesis 2:}

There is a significant positive relationship between the board of director responsibility and the performance of insurance listed firms in Nigeria.

\subsubsection{Board of Director Accountability and Firm performance}

Board of director accountability was defined in this paper as bridging the gap between board commitments, task, and roles that are aligned with stakeholder expectations. In the early wake of corporate scandals that contributed to global financial and economic crisis in recent years, investors, policy makers, and others stakeholders have called for director's accountability to their shareholders (Naaraayanan\& Nielsen, 2016). However, the accountability of boards to stakeholder expectation is regarded as a critical issue in promoting the performance every firm been it private or public sector (Keay, 2016; Nuhu\& Ahmad, 2016). The fact remains that board accountability is essential to shareholders and investors right. Hence, recent investigation has argued that board accountability is in relation to a number of elements that boards must first accept the responsibility and the need to be answerable to the shareholder's return (Keay, 2016).

However, directors are mostly or rarely subject to lawsuits by their shareholders or stakeholders, and when they are found guilty in any cases, often are lead to dismissed (Adegbite 2015; Amour et al. 2009; Black et al. 2006; Brennan et al., 2016). Moreover, the incidences of voting and electoral is another challenge of directors who are infrequent, that indicating that owners rarely grip or hold directors very accountable by proposing replacement or alternative candidates or person to fill the vacuum or vacant for directorship position (Bebchuk, 2007; Choi et al., 2016). Thus, some researchers argued that directors infrequently are challenged particularly in a time of voting to replace directors following lawsuits and law enforcement action (Farber, 2005; Ferris et al. 2007; Kuyper \&Bäckstrand, 2016; Torchia\&Calabrò, 2016). While another stream of research contended that, many directors are afraid of shareholders lawsuits, hence, will likely wish to rather leave boards to avoid punishment by shareholders (Aggarwal, Dahiya\&Prabhala, 2015; Choi et al., 2016). Although, some independent directors or non-executive also found guilty thereafter lose their positions on the boards due to their selfish interest rather than defending or representing the interest of their shareholders by colluded with management for financial irregularities (Brennan et al., 2016; Choi et al., 2016; Gilson, 1990; Srinivasan, 2005; Fich and Shivdasani, 2007; Ertimur et al., 2012).

Hence, theoretically, to increase board accountability, there should be improved in directors' incentive and welfare to monitor affairs of management activities and reduce agency conflict and entrenchment (Naaraayanan\& Nielsen, 2016). In another stream of argument, it can be contended that fear of legal accountability and liability could deter individuals director from serving on the board (Choi, Fisch, Kahan and Rock, 2016; Romano, 1989; Sahlman, 1990). In another hand, argued that insisting on board accountability make them risk averse and thus reduce the effectiveness of the board. Despite a rich literature on corporate directors, direct evidence of whether accountability deters individuals from serving on corporate boards is scant.

The little previous literature found on director accountability has merely focused on examining whether Non-executive (independent) directors experience litigation risk or danger (Armour, Black, 
Cheffins\&Nolan, 2009; Black, Cheffins\&Klausner, 2006; Brochet\& Srinivasan, 2014). While other examining whether directors were held accountable for their action or wrong doing through shareholder/owner voting in director elections position (Cai, Garner \& Walking, 2009; Fischer, Gramlich, Miller \& White, 2009; Guercio, Seery\&Woidtke, 2008). While other recent studies argued that directors are held accountable for mismanagement and corporate misfortunes through law enforcement or either through lawsuits (Brennan et al., 2016; Choi et al., 2016; Kuyper \&Bäckstrand, 2016; Torchia\&Calabrò, 2016). Therefore, due to mixed argument on director accountability and scant literature for the fact that based on these paper literature knowledge no studies have link board accountability to firm performance, this paper, develop the following hypothesis;

\section{Hypothesis 3:}

There is a significant positive relationship between the board of director accountability and the performance of insurance listed firms in Nigeria.

\section{Theoretical Framework}

This paper is rooted in one theory and supported by two theoretical perspectives in investigating the relationship between corporate governance mechanisms/characteristics and the performance of insurance listed firms in Nigeria.Hence, there are numerous well-developed theories that are available to scholars/researchers to aid or exploring the concepts of corporate governance mechanisms. Though, these paper is rooted in Agency theory and supported by managerial hegemony theory, and stewardship theory.

Agency theory has in recent time continue to gain the support of recent studies that were acknowledged as the major and dominant theory as against numerous other theories in corporate governance research (Aguilera et al., 2008; Johnson, 2008; Lawal, 2012; Nuhu\& Ahmad, 2016; Zahra \& Pearce, 1989). Hence, agency theory is merely built on the believed and premise that separation of the owner from an agent will create a bottleneck between the two parties (Aguilera et al., 2008; Lawal, 2012). Therefore, agency theory model believed that separation of ownership (shareholder) and control (agent) creates a conflict of interest between and involves risk sharing between the two (Aguilera et al., 2008; Nuhu\& Ahmad, 2016). Implicit in the belief that the manager or agent will be ambitious or driven by their self-interest rather than the interest of the owner (principal) (Lawal, 2012). Though managers or agent are seeing as a rational, they cannot be fully trusted to remain loyal and faithful for the best interest of their shareholder (principal) since the agent are also pursuing their self-interested (Padilla, 2002; Lawal, 2012). Hence, the board, are considered as an intermediary, that is expected to resolve the conflict of interest that exists between principal and agent (Nuhu\& Ahmad, 2016). However, to address the conflicting interest or agency problem, between the owner and manager, the agency theory acknowledged the important role of the board of directors as mechanisms of owners (shareholders) in subduing the manager's actions (Lawal, 2012; Stiles \& Taylor 2001).

The first supported theory is managerial hegemony, managerial hegemony theory is advocated that boards of directors are seeing and just a statutory additions that are full or dominated by the top management (Lorsch\& MacIver, 1989; Mace, 1971; Vance, 1983). Management hegemony believed that boards of the director only play a passive role in strategic decision making or directing the corporation (Lorsch\& MacIver, 1989; Mace, 1971; Vance, 1983). While the second supported theory is stewardship theory, that postulates or assumes that managers are intrinsic or motivated to accomplish the job before them or a desire to achieve target goal or objective to the company (Lawal, 2012; Donaldson \&Muth, 1998) in gaining intrinsic satisfaction and motivation by performing tasks before them. This theory argued that agent or managers need authority to pursue and desire recognition from their superiors (Riana, 2008). Hence, the board of director role and responsibility is a matter of strategy which is seen as contributing factor to this managerial perspective (Donaldson \&Muth, 1998; Freeman, 1999; Gay, 2002; Hillman et 
al., 2000; Johnson et al., 1996; Lawal, 2012; Nicholson \& Kiel, 2007; Nuhu\& Ahmad, 2016).

\section{Figure 1: Framework}

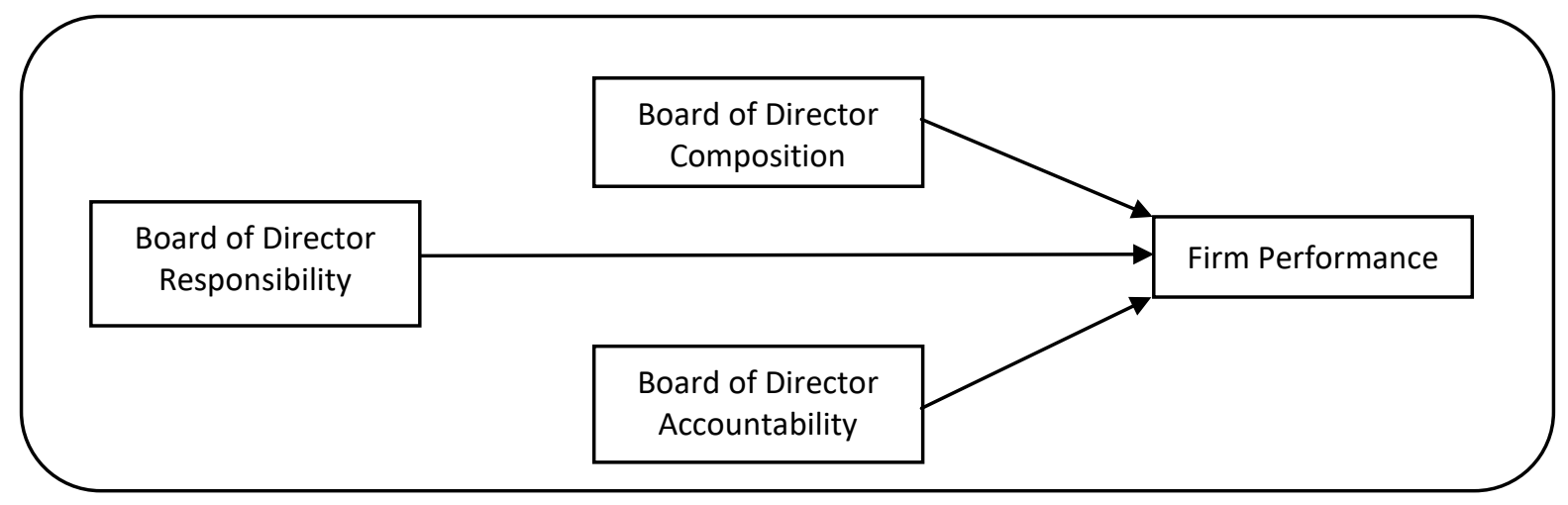

\section{Methodology}

The used of questionnaires for this study were adopted from prior researchers. Self-administered questionnaires were carried out to examine the formulated and test hypotheses, using the total population of 283 board of directors of insurance firm listed in the Nigeria stock exchange as at January 2016 as respondents for this paper. Sample size determination using Krijcie and Morgan (1970) table were adopted which resulted in 165 sample for the study. Salkind (1997) suggested that addition of $10 \%$ or $40 \%$ of the sample should be added to sample size to avoid low response rate. The ideas is to increase sample size with $10 \%$ so as to improve the response rate (Salkind, 1991). Thus, the high the response rate, the perfect the results (Salkind, 1991). Therefore, $10 \%$ of 165 is 16.5 approximately 17. Hence, 182 questionnaires were randomly distributed among the target population (respondents) with help of Nigeria stock exchange and security and exchange commission. Thus, out of 182 questionnaires administered, 117 were duly completed and returned. Although, it is a close-ended format questionnaires that based on 5-point Likert scale of 1-5, where, $5=$ strongly disagree, $4=$ disagree, $3=$ no idea, $2=$ agree, $1=$ strongly agree. Hence, out of 117 number of questionnaires duly completed and returned, which represents the response rate of 64.2857 percent (64 percent) of the study sample. 3 out of 117 questionnaires returned were invalid. Hence, the final number of 114 (63\%) usable questionnaires were used for the analysis after thorough data screening. Furthermore, statistical software for social science (SPSS version 22) were first employed for data screening and preliminary analysis while Smart PLS 2.0 software was used to conducted or carry out the partial least squares (PLS) analysis (Nasiru\&KeatOoi, 2015; Olusegun, Ashari\&Nordin 2014; Ringle, Wende, \& Will, 2005).

\section{Results}

The study adapted measurement from the work of Okpara, (2011) for board of director composition; Ammann, Oesch and Schmid (2011) for board of director accountability; Okpara, (2011) for board of directors' responsibilities; Rettab et al (2009) for firm performance.The analysis of demographic characteristics of the respondents is as follow: in term of gender; male dominated by 85.09 percent $(\mathrm{N}=97)$ as against females with only 14. 91 percent $(\mathrm{N}=17)$. With regard to the position of the respondents, chairmen 1.75 percent $(\mathrm{N}=2)$, chairperson 2.63 percent $(\mathrm{N}=3)$, managing director/chief executive officer 15.75 percent $(\mathrm{N}=18)$, directors more than 59.65 percent $(\mathrm{N}=68)$, while independent director 14.91 percent $(\mathrm{N}=17)$, secretary 1.75 percent $(\mathrm{N}=2)$ and others 3.51 percent $(\mathrm{N}=4)$ more than half (55 percent; $\mathrm{N}=128)$ were from urban areas compared to 45 percent $(\mathrm{N}=107)$ who were known or called by another name on the boards. For the age of the respondent; between the age of 31-40 are 29.80 percent $(\mathrm{N}=38), 41-50$ age are 51.7 percent $(\mathrm{N}=56)$, while 51-60 fall on 17.70 percent $(\mathrm{N}=14)$ and 61 and above 0.8 percent $(\mathrm{N}=6)$. For education or qualification, the respondent with $\mathrm{Ph}$. D.is 5.26 percent $(\mathrm{N}=6)$, while 
the majority of the respondents have master degree with 66.67 percent $(\mathrm{N}=76)$, and 28.07 percent $(\mathrm{N}=32)$ have B.Sc and other qualifications. Also, for the number of board the director is presently serving, the majority of the respondent of 92.98 percent $(\mathrm{N}=106)$ are serving only in one board of director of a firm, while 6.14 percent $(\mathrm{N}=7)$ are serving in two board of director while 0.88 percent $(\mathrm{N}=1)$ serving in three board of director.

The study adopted and use Smart PLS 2.0 software in the tested model by conducting partial least square (PLS) analysis (Ringle et al., 2005). As recommended, in determining the study minimum sample size is by multiplying the number of the arrows or highest arrows pointing to dependent variable or to a particular endogenous construct by 10 (Barclay, Higgins \& Thompson, 1995; Nasiru\&KeatOoi, 2015). Hence, in the case of this study, we have one dependent variable (endogenous construct) with three arrows pointing or directly at it, that signifying a least of a sample size of 30 would be sufficient and enough for the study analysis. In addition, as suggested and recommended that if the G*power analysis is employed, 112 observations are required in order to attain a statistical power (G*power) of 95 percent for detecting $\mathrm{R}^{2}$ values of at least 0.21 (5 percent probability of error) (Hair, Hult, Ringle\&Sarstedt, 2014). Therefore, given the 114 returned and usable questionnaires/participants, it is, therefore, believed that Smart PLS is the most appropriate tool/technique to be used in testing this study direct hypotheses.

\section{Measurement Model}

The convergent and discriminant validity was used in this study to test and check for the adequacy of the items or indicators in measuring the variable/construct that they are supposed to be at the right construct to measure. Hence, for the convergent validity (Bagozzi\& Phillips, 1982; Nasiru\&KeatOoi, 2015), the construct reliability, as well as indicators' reliability, were assessed (Nasiru\&KeatOoi, 2015; Peter, 1981). Therefore, to examine the study indicators reliability, the loadings were performed and they were all above the threshold or recommended 0.7 (Hair et al., 2014) value parameter. Also, for the reliability and validity of the construct, composite reliability (CR) and the average variance extracted (AVE) were all examined. Hence, the composite reliability (CR) are all above 0.7 and the average variance extracted (AVE) are well above the recommended or threshold of 0.5 (Bagozzi\& Yi, 1988; Hair et al., 2014). Precisely, the lowest composite reliability (CR) was 0.796 and the lowest average variance extracted (AVE) was 0.595 . See Table 1 convergent validity.

\section{Table 1}

The Items loading, Average Variance Extracted (AVE) and Reliabilities

\begin{tabular}{lcccc}
\hline Latent Variable & Code & Loadings & AVE & CR \\
\hline Board of Director Accountability & BDA1 & 0.881 & 0.704 & 0.904 \\
& BDA2 & 0.816 & & 0.876 \\
Board of Director Composition & BDA5 & 0.774 & & \\
& BDA6 & 0.879 & 0.595 & \\
Board of Director Responsibility & BDC10 & 0.545 & & \\
& BDC11 & 0.892 & 0.608 & 0.796 \\
Firm Performance & BDC5 & 0.819 & 0.663 \\
\hline
\end{tabular}


In addition, the study also examined the cross-loadings of the construct items as well as the inter-construct correlation matrix with the square root of the average variance extracted (AVE) across the diagonal in examining discriminant validity of the study constructs. Hence, the items below the threshold of 0.5 were deleted as recommended by Hair et al., (2014). Table 2 shown cross-loading of the item loads (shadowed) higher on its each respective constructs, this indicated that shadowed item loads implies discriminant validity. In Table 3, Fornell and Larcker (1981) contended that the square root of each reflective construct's average variance extracted (AVE) should be greater than any level of correlations involving in the construct. Therefore, the study model has met up as well as satisfied the threshold of validity and reliability criteria. Hence, the study could run to establish or determine the descriptive and structural modeling predictive power. The following shown Table 3 with an illustration of the descriptive for the study constructs in the model.

\section{Table 2}

Latent Variable Correlations and Square Root of Average Variance Extracted (AVE), Mean and Standard Deviation

\begin{tabular}{|c|c|c|c|c|c|c|}
\hline Latent Variable & BDA & BDC & BDR & FP & Mean & Std. Dev. \\
\hline Board of Director Accountability (BDA) & 0.704 & & & & 3.14 & 0.664 \\
\hline Board of Director Composition (BDC) & 0.305 & 0.595 & & & 2.4 & 0.596 \\
\hline Board of Director Responsibility (BDR) & -0.175 & -0.109 & 0.663 & & 2.5 & 0.547 \\
\hline Firm Performance (FP) & 0.578 & 0.476 & -0.067 & 0.833 & 2.74 & 0.522 \\
\hline
\end{tabular}

Note: The values in bold are the square root of AVE across diagonal and off-diagonal are the correlation among the latent variables

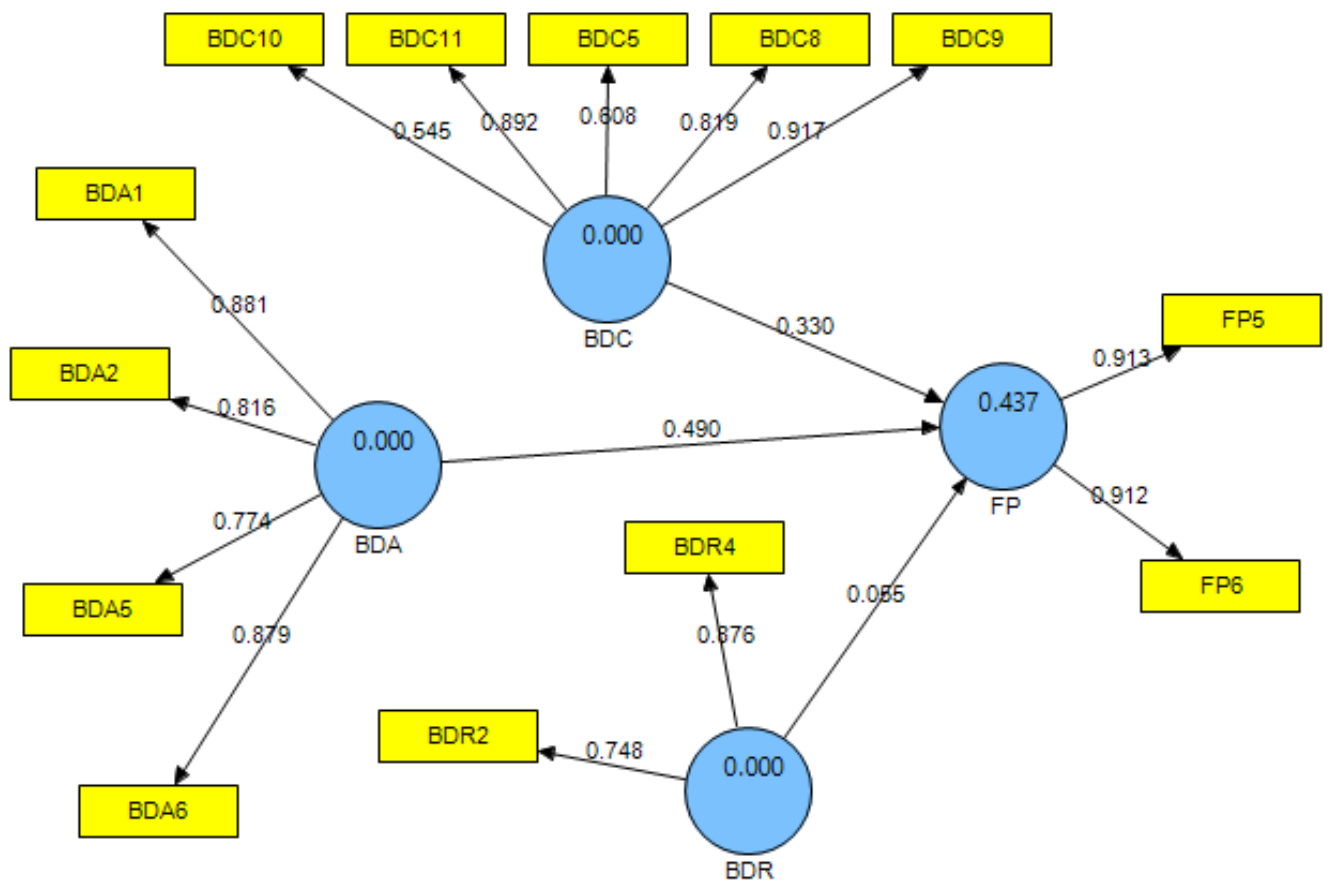

Figure 1: Measurement Model 


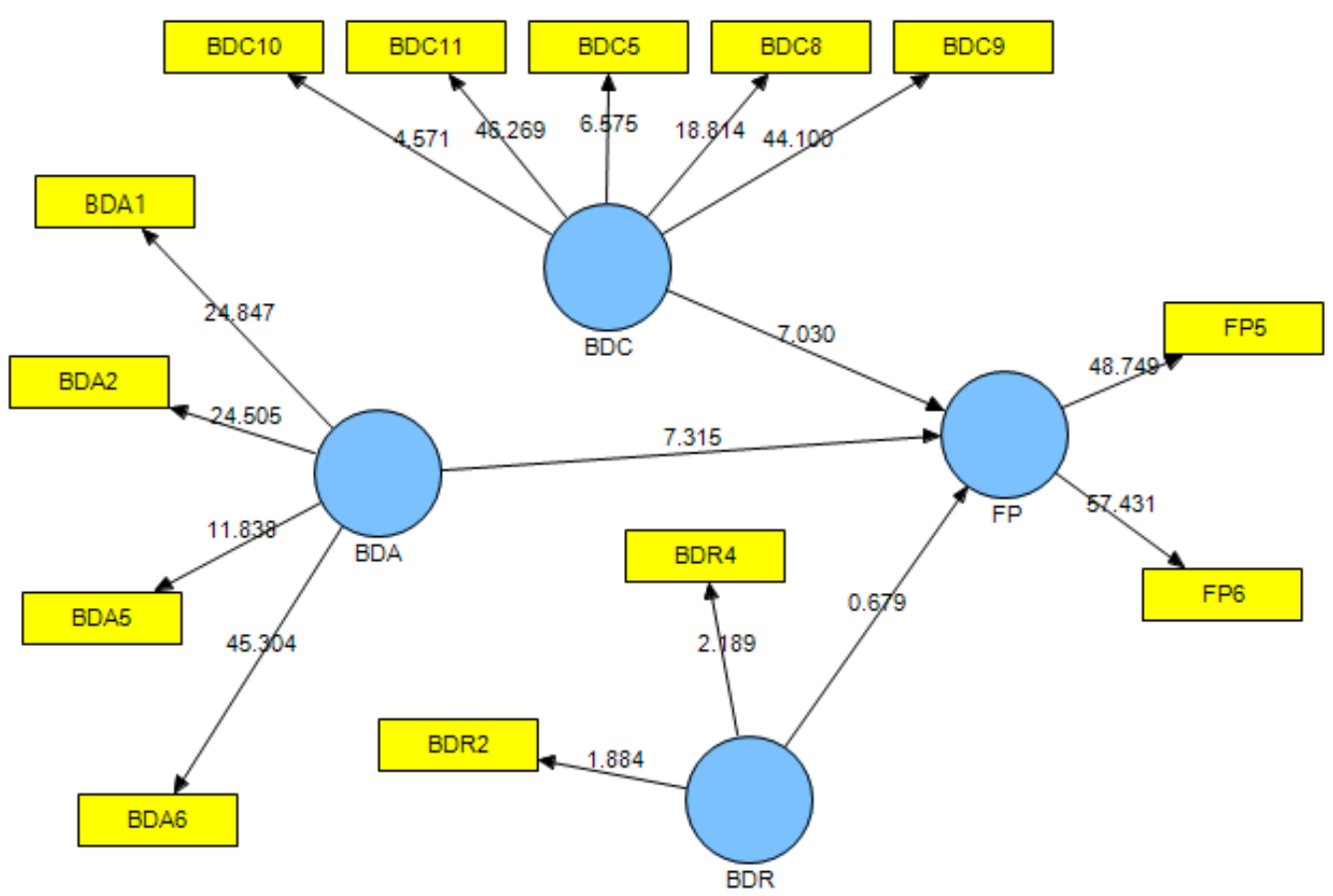

Figure 2. Structural Model

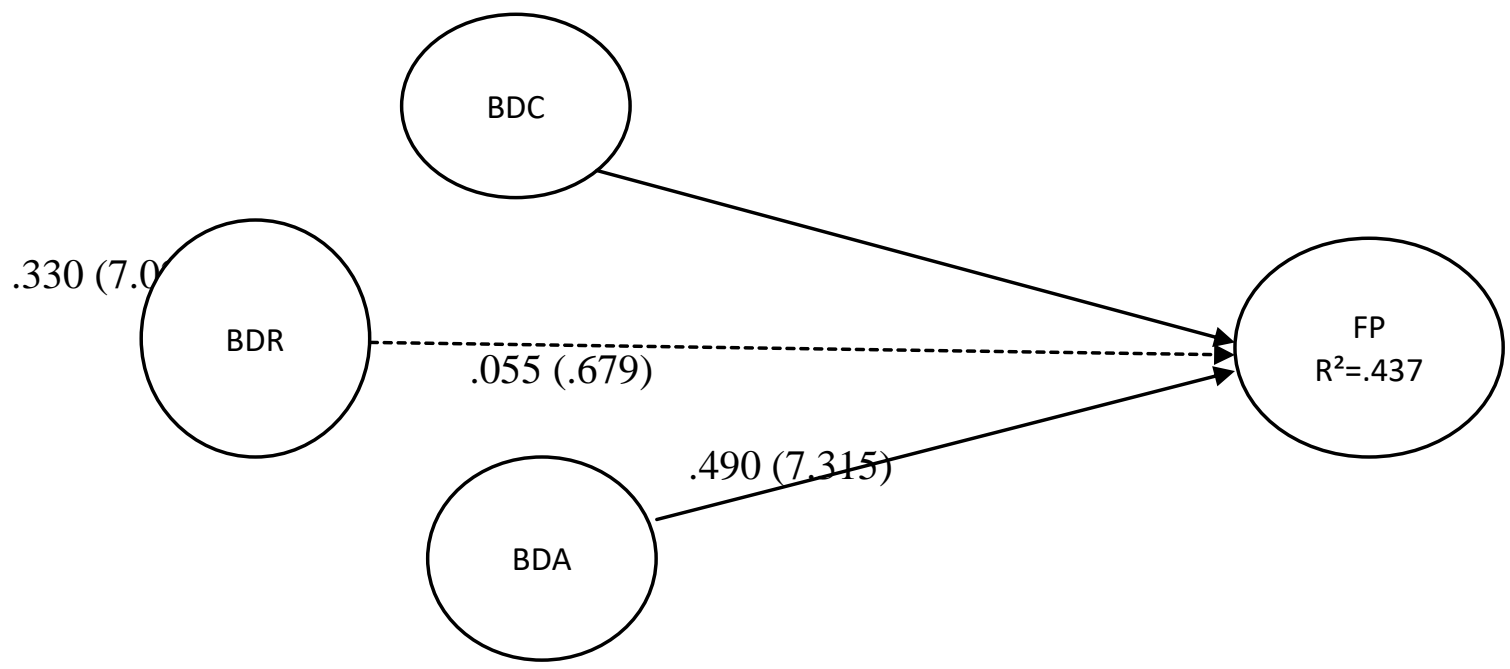

\section{Figure 3: Validated Structural Model}

Figure 3, shown the validated structural model. The values in parentheses indicate t-values; solid lines indicate significant relationships $(\mathrm{p}<0.01)$ respectively. The dotted line indicates no significant but positive relationship. 


\section{Table 3}

Structural Model Assessment (Hypothesis Test)

\begin{tabular}{ccccccl}
\hline Hypothesis & Relationship & $\begin{array}{c}\text { beta } \\
\text { value }\end{array}$ & $\begin{array}{c}\text { Std. } \\
\text { Error }\end{array}$ & t value & p value & Decision \\
\hline H1 & BDC -> FP & 0.330 & 0.047 & 7.030 & $0.000^{* * *}$ & Supported \\
H2 & BDR -> FP & 0.055 & 0.081 & 0.679 & 0.500 & Not Supported \\
H3 & BDA -> FP & 0.490 & 0.067 & 7.315 & $0.000^{* * *}$ & Supported \\
\hline
\end{tabular}

$* * * \mathrm{P}<.001$

\section{Discussion}

The aim of this paper was to investigate the relationship between corporate governance mechanisms and firm performance of the insurance listed firms in Nigeria. It is postulated that corporate governance positively relatesto firm performance. In general, the finding of the study analysis has shown that the empirical supported the important role board of directors played to improving insurance listed firm performance (Lawal, 2016; Nuhu\& Ahmad, 2017). Hence, there is a positive statistically significant relationship between the board of director composition and the performance of insurance listed firms in Nigeria. Therefore, the hypothesis one supported $(\beta=.330 ; \mathrm{T}$ value $=7.030)$. The results of this findings are consistent with the prior findings (Armstrong, 2005; Auld \&Gulbrandsen 2010; Krishnamurti\&Sevic applied, 2013; Klapper\& Love, 2004; Klomp\&Haan, 2008; Zehir, Çınar\&Şengül, 2016) who showed that the composition of board of director influence the performance of insurance firms. The result of hypothesis two showed not supported. The findings showed that there is no relationship between the board of director responsibility and the performance of insurance listed firms in Nigeria. Therefore, the hypothesis is not supported $(\beta=.055$; $\mathrm{T}$ value $=0.679)$. This result is also consistent with the prior studies (Donaldson, 1999; Freeman, 1999; Gibson, 2000). That there is no statistically significant relationship between the board of director responsibility and the performance of insurance listed firms in Nigeria. Hence, in line with hypothesis three formulated, the results supported the hypothesis. The findings showedsignificant result between the board of director accountability and the performance of insurance firm in Nigeria $(\beta=.490$; $\mathrm{T}$ value=7.315). Previous studies are also consistent with these findings (Epstein et al., 2015; Gompers et al., 2003; Gómez-Bezares et al., 2016; Jiraporn\& Ning, 2007).

Therefore, from the overall findings of this study, two of the hypotheses showing significant positive relationships while one of the hypotheses showing no relationship. Hence, this study showed that board of director mechanisms (composition and accountability) influence the performance of insurance firm in Nigeria. The findings were anticipated to have significant positive to firm performance. For example, Hermalin and Weisbach (1988); Jizi (2017); Ngulumbu and Aduda (2016) and Lawal (2016) contended in their finding that poor performance is mostly caused by lack of implementations. Hence, these mechanisms or features or variables have shown the influence to the corporate performance. Therefore, this paper recommended that directors of directors (agent) should accountable to the shareholders (principal) improve the performance of the insurance firm. Again, the composition of the board of director should comprise $\mathrm{CEO} /$ managers/directors with integrity that will influence the performance of insurance company in Nigeria. The future researchers to improve on this study through new methodological and theoretical approaches.

\section{Conclusion and Future Researchers}

In this paper, numerous related variables of corporate governance to improved firm performance were being examined. Hence, the results of the paper analysis have indicated that the corporate transparency and accountability, shareholder rights are statistically significant except corporate behavior that has no relationship. There is need for improvement on the prior studies on corporate governance that have been relying on one theory or depended on one theory for so long particularly when investigating on the issue of corporate governance mechanisms to firm performance (Daily et al, 2003; Lawal, 2016; Hillman 
\&Dalziel, 2003; Jensen \&Meckling, 1976; Johnson et al, 1996; Zahra \& Pearce, 1989). The inconsistency on the previous study has made it unthinkable for a single theory to suit and flow current research (Kiel \&Nickholson, 2007). Also, there is a very urgent need for a change of models and more of observational studies to truly comprehend the significance of corporate board (Donaldson \&Muth, 1998; Eisenhardt, 1989; Jackling \&Johl, 2009).

Again, another important improvement of this paper is methodology over prior studies is the use of primary data as recommended by recent previous studies (Lawal, 2016; Johl et al, 2015; Nath, 2015), Corporate governance studies have depended on particular methodology and firm performance measures and not considering the way that the circumstance which stimulates the utilization of such approach, in any case, has gone out of date. In this manner can't longer track the variable to be anticipated. The time is a good fit for the utilization of extended methodology that took into account primary examination (Finegold et al., 2007; Lawal, 2016; Rechner\& Dalton 1991). Advancement of performance measures as a new era of observational studies is starting to investigate another option of measuring corporate governance performance, for example, using the primary methodology and "Structural Equation Modeling-Partial Least Square (SEM-PLS) for analysis". These models have so far demonstrated a lot of guarantees (Peterson et al, 2012; Hair et al, 2013; Henseler 2012). Partial least squares structural equation modeling is a rigorous application that givesbetter results with a higher acceptance and long range planning researchers (Hair et al, 2013 p.12).

Despite many years of corporate governance studies, the current findings are wholly asymmetrical with the majority of research originating from developing countries like US and UK together with others developed economies nation (Huse, 2007; Jackling \&Johl, 2009; Johnson et al., 1996; Vafeas\&Theodorou, 1998; Yermack, 1996;). There is an urgent requirement or need for developing and emerging economies like Africa, especially Nigeria in driving force where there is a slight of observation or empirical studies. Companies' level studies from developing nations, particularly those with the frail legitimate environment could be significant to the field of study (Klapper\& Love, 2002). Over the previous year, lack of the adequate and sufficient documented studies from an African point of view, particularly the emerging economies like Nigeria has without a doubt impair the policy makers in forging suitable reason for enhanced corporate governance. A unified, consensus and harmonized code of best practice on the level of compliance and sanctions for non-compliance will improve the performance of insurance listed firms in Nigeria.

The limitation of this paper, the study could not capture all the corporate governance mechanisms in predicting others variables that would influence or improvement firm performance. Therefore, the paper recommended that the future studies should extend by including others corporate governance variables such as board meeting, chief executive officer duality, diversity among others using primary data and other statistical techniques like AMOS-Structural Equation Modeling (AMOS-SEM). Thus, future research should also considermulti-group variable for future analysis which this paper could not capture and strategically employ demographic variables with various groups.

\section{References}

Adamu, A. (2009). The effects of the global financial crisis on the Nigerian economy.Available at SSRN 1397232.

Adegbite, E. (2015). Good corporate governance in Nigeria: Antecedents, propositions, and peculiarities. International Business Review, 24(2), 319-330.

Adjaoud, F., \& Ben-Amar, W. (2010). Corporate governance and dividend policy: shareholders' protection or expropriation? Journal of business finance \& accounting, 37(5-6), 648-667.

Adjaoud, F., D. Zeghal and S. Andaleeb (2007). The effect of a board's quality on performance: a study 
of Canadian firms, Corporate Governance: An International Review, 15(4), 623-635.

Aglietta, M. (2000). Shareholder value and corporate governance: some tricky questions. Economy and Society, 29(1), 146-159.

Aguilera, R.V., Filatotchev, I., Gospel, H., \& Jackson, G. (2008). An organizational approach to comparative corporate governance: Costs, contingencies, and complementarities. Organization Science, 19(3), 475-494. http://dx.doi.org/10.1287/orsc.1070.0322

Akinkoye, E. Y., \&Olasanmi, O. O. (2014). Corporate governance practice and level of compliance among firms in Nigeria: an Industry analysis. Journal of Business \& Retail Management Research, 9(1).

Al-Matari, E. M. A. (2014). Corporate governance and performance of non-financial public listed firms in Oman (Doctoral dissertation, Universiti Utara Malaysia).

Amar G. (2001). Saint and Sinners: Who's Got Religion, CLSA (Credit Lyonnais Securities Asia), CG Watch, Corporate Governance in Emerging Markets, pp. 202-205)

Ammann, M., Oesch, D., \&Schmid, M. M. (2011). Corporate governance and firm value: International evidence. Journal of Empirical Finance, 18(1), 36-55.

Ararat, M., Black, B. S., \&Yurtoglu, B. B. (2017). The effect of corporate governance on firm value and profitability: Time-series evidence from Turkey. Emerging Markets Review, 30, 113-132.

Armour, J., Enriques, L., Hansmann, H., \&Kraakman, R. (2017). The Basic Governance Structure: The Interests of Shareholders as a Class

Armstrong, E. (2005). Integrity, transparency, and accountability in public administration: Recent trends, regional and international developments and emerging issues. United Nations, Department of Economic and Social Affairs, 1-10.

Auld, G., \&Gulbrandsen, L. H. (2010). Transparency in nonstate certification: consequences for accountability and legitimacy. Global Environmental Politics, 10(3), 97-119.

Avgouleas, E. (2008). Financial regulation, behaviour finance, and the financial credit crisis in search of a new regulatory model.Retrieved from http. papers. ssrn.com on, 24(11)

Ayuso, S., \&Argandoña, A. (2007). Responsible Corporate Governance: Towards a Stakeholder Board of Directors? (IESE Business School Working Paper No. 701). Retrieved May 14, 2015, from http://www.iese.edu/research/pdfs/DI-0701-E.pdf

Bagozzi, R. P., \& Phillips, L. (1982). Representing and testing organizational theories: a holistic construal. Administrative Science Quarterly, 27, 459-489.

Bagozzi, R. P., \& Yi, Y. (1988).On the evaluation of structural equation models. Journal of the Academy of Marketing Science, 16, 74-94. http://dx.doi.org/10.1007/BF02723327

Barclay, D. W., Higgins, C. A., \& Thompson, R. (1995). The partial least squares approach to causal modeling: Personal computer adoption and use as an illustration. Technology Studies, 2, 285-309.

Berger, P. G., \&Ofek, E. (1995).Diversification's effect on firm value. Journal of financial economics, 37(1), 39-65

Berle, A., \& Means, G. (1932). The Modern Corporation and Private Property. New York, NY: Macmillan.

Berman, S. L., Wicks, A. C., Kotha, S., \& Jones, T. M. (1999). Does stakeholder orientation matter? The relationship between stakeholder management models and firm financial performance. Academy of Management Journal, 42(5), 488-506.

Berrone, P., Surroca, J., \&Tribó, J. A. (2007). Corporate ethical identity as a determinant of firm performance: A test of the mediating role of stakeholder satisfaction. Journal of Business Ethics, 76(1), 35-53.

Borgia, F. (2005). Corporate Governance \& Transparency Role of Disclosure: How to Prevent New Financial Scandals and Crimes. American University Transnational Crime and Corruption Center School of International Service.

Brammer, S. J., \&Pavelin, S. (2006). Corporate reputation and social performance: The importance of fit. Journal of Management Studies, 43(3), 435-455. 
Cadbury, S.A. (2000), the corporate governance agenda, Corporate Governance: An International Review, $8(1), 7-15$.

Cadbury, Sir Adrian (1992) Report of the Committee on the Financial Aspects of CorporateGovernance, London: Gee.

CBN (2011), on capitalization of eight Nigerian banks, Abuja: Central Bank of Nigeria.

Chandler, M. E. J. (1962). The Lower Tertiary Floras of Southern England...: By Marjory Elizabeth Jane Chandler...Flora of the Pipe-clay Series of Dorset (Lower Bagshot).British Museum.

Clarke, T. (2007). International Corporate Governance: A Comparative Approach, Routledge, Abingdon.

Cohen, J. (1988). Statistical Power Analysis for the Behavioral Sciences. Hillsdale, New Jersey. Lawrence Erlbaum.

Daily, C., Dalton, D., \&Cannella, A. (2003). Corporate governance: Decades of dialogue and data. Academy of Management Review, 28(3), 371-382.

Denis, D. J., Denis, D. K., \& Sarin, A. (1997). Agency problems, equity ownership, and corporate diversification. The Journal of Finance, 52(1), 135-160.

Donaldson, L., \&Muth, M.M. (1998). Stewardship theory and board structure: A contingency approach. Corporate Governance- An International Review, 6(1), 5-28.

Donaldson, W.H. (2003) corporate governance, Business Economics, 38:16-20.

Eeckloo, K., Van Herck, G., Van Hulle, C., \&Vleugels, A. (2004). From Corporate Governance to Hospital Governance: Authority, transparency and accountability of Belgian non-profit hospitals' board and management. Health Policy, 68(1), 1-15.

Ehikioya, B. I. (2009). Corporate governance structure and firm performance in developing economies: evidence from Nigeria. Corporate Governance: The International journal of business in society, 9(3), 231-243.

Eisenberg, T, S. Sundgren and M. T. Wells (1998). Larger board size and decreasing firm value in small firms, Journal of Financial Economics, 48(1), 35-54.

Epstein, M. J., Buhovac, A. R., \&Yuthas, K. (2015).Managing social, environmental and financial performance simultaneously. Long range planning, 48(1), 35-45.

Evans, N., \& Sawyer, J. (2010).CSR and stakeholders of small businesses in regional South Australia. Social Responsibility Journal, 6(3), 433-451.

Falk, R. F., \& Miller, N. B. (1992).A primer for soft modeling. Ohio: The University of Akron Press.

Fama E. and Jensen, M. (1983). "Separation of Ownership and Control," Journal of Law and Economics (June), pp. 301-326.

Fernández-Gago, R., Cabeza-García, L., \& Nieto, M. (2016). Corporate social responsibility, the board of directors, and firm performance: an analysis of their relationships. Review of Managerial Science, 10(1), 85-104.

Ferro, C., Ferro, C., Padin, C., Padin, C., Svensson, G., Svensson, G., \&Høgevold, N. M. (2017).Validating a framework of stakeholders in connection to business sustainability efforts in supply chains. Journal of Business \& Industrial Marketing, 32(1), 124-137.

Finegold, D., Benson, G.S., \& Hecht, D. (2007). Corporate boards and company performance: a review of research in light of recent reforms. Corporate Governance: An International Review, 15(5), 865878. http://dx.doi.org/10.1111/j.1467-8683.2007.00602.x

Fombrun, C. (1996). Reputation.John Wiley \& Sons, Ltd.

Fombrun, C., \&Shanley, M. (1990). What's in a name? Reputation building and corporate strategy. Academy of Management Journal, 33(2), 233-258.

Fornell, C., \&Larcker, D. F. (1981). Structural equation models with unobservable variables and measurement error: algebra and statistics. Journal of Marketing Research, 18(3), 328-388.

Freeman, R. E. (1984). Divergent stakeholder theory. Academy of management review, 24(2), 233-236.

Friedman, A. (1970). Foundations of modern analysis. Courier Corporation.

Garay, L., Font, X., \& Pereira-Moliner, J. (2017). Understanding sustainability behaviour: The 
relationship between information acquisition, proactivity, and performance. Tourism Management, 60, 418-429.

Gay, K. (2002). Board theories and governance practices: Agents, Stewards and their evolving relationships with stakeholders. Journal of General Management, 27(3), 36-61.

Gibson, K. (2000). The moral basis of stakeholder theory. Journal of business ethics, 26(3), 245-257.

Global Issues (2009). Global Financial Crisis: Crisis in Context, http://www.globalissues.org/article/768/global-financial-crisis [accessed 25th October 2015]

Gómez-Bezares, F., Przychodzen, W., \&Przychodzen, J. (2016). Corporate Sustainability and Shareholder Wealth-Evidence from British Companies and Lessons from the Crisis. Sustainability, 8(3), 276.

Gompers, P., Ishii, J., \&Metrick, A. (2003).Corporate governance and equity prices. The quarterly journal of economics, 118(1), 107-156.

Guerra, S., Fischmann, A., \& Filho, C.A.P.M. (2009). An agenda for board research. Corporate Ownership and Control, 6(3), 196-202.

Hair, J. F., Ringle, C. M., \&Sarstedt, M. (2014). Partial least squares structural equation modeling: Rigorous applications, better results, and higher acceptance. Long Range Planning, 46(1-2), 1-12

Harrison, J. S., \& Freeman, R. E. (1999). Stakeholders, social responsibility, and performance: Empirical evidence and theoretical perspectives. Academy of Management Journal, 42(5), 479-485.

Harvey Pamburai, H., Chamisa, E., Abdulla, C., \& Smith, C. (2015). An analysis of corporate governance and company performance: a South African perspective. South African Journal of Accounting Research, (ahead-of-print), 1-17.

Henseler, J. (2012). PLS-MGA: A non-parametric approach to partial least squares-based multi-group analysis. In Challenges at the interface of data analysis, computer science, and optimization (pp. 495-501). Springer Berlin Heidelberg

Hillman, A. J., \&Keim, G. D. (2001). Shareholder value, stakeholder management, and social issues: what's the bottom line? Strategic management journal, 125-139.

Hillman, A. J., Cannella, A. A., \&Paetzold, R. L. (2000). The resource dependence role of corporate directors: a Strategic adaptation of board composition in response to environmental change. Journal of Management Studies, 37(2), 235-256.

Hillman, A., \& Dalziel, T. (2003). Boards of directors and firm performance: Integrating agency and resource dependence perspectives. Academy of Management Review, 28(3), 383-396.

Hosmer, L. T. (1994). Strategic planning as if ethics mattered. Strategic Management Journal, 15(S2), 17-34.

Huse, M. (2007).Boards, Governance and Value Creation. Cambridge: Cambridge University Press. http://dx.doi.org/10.1017/CBO9780511611070

Hutchison, R. M., Womelsdorf, T., Allen, E. A., Bandettini, P. A., Calhoun, V. D., Corbetta, M., $\&$ Handwerker, D. A. (2013). Dynamic functional connectivity: promise, issues, and interpretations. Neuroimage, 80, 360-378.

Jackling, B. and S. Johl (2009). Board structure and firm performance: evidence from India's top companies, Corporate Governance: An International Review, 17(4), 492-509.

Jensen W.H. and M. Meckling (1976). Theory of the firm: managerial behaviour, agency costs and ownership structure, Journal of Financial Economics, 3(4), 305-360.

Jensen, M. (2001). Value maximization, stakeholder theory, and the corporate objective function. European financial management, 7(3), 297-317.

Jiraporn, P., \& Ning, Y. (2006).Dividend Policy, Shareholder Rights, and Corporate Governance (Digest Summary). Journal of Applied Finance, 16(2), 24-36.

Jiraporn, P., Kim, Y. S., Davidson, W. N., \& Singh, M. (2006). Corporate governance, shareholder rights and firm diversification: An empirical analysis. Journal of Banking \& Finance, 30(3), 947-963.

Jizi, M. (2017).The Influence of Board Composition on Sustainable Development Disclosure. Business Strategy and the Environment. 
Johanson, D. (2008). Corporate governance and board accounts: exploring a neglected interface between boards of directors and management. Journal of Management and Governance, 12(4), 343-380. http://dx.doi.org/10.1007/s10997-008-9065-6

Johl, S. K., Kaur, S., \& Cooper, B. J. (2015). Board characteristics and firm performance: evidence from Malaysian public listed firms. Journal of Economics, Business, and Management, 3(2).

Johnson, J.L., Daily, C.M. and Ellstrand, A.E. (1996) Board of Directors: A review and research agenda, Journal of Management, 22: 409-438.

Jones, T. M. (1995). Instrumental stakeholder theory: A synthesis of ethics and economics. Academy of management review, 20(2), 404-437.

Khongmalai, O., Tang, J. C., \&Siengthai, S. (2010). Empirical evidence of corporate governance in Thai state-owned enterprises. Corporate Governance: The International journal of business in society, 10(5), 617-634

Klapper, L. F., \& Love, I. (2004).Corporate governance, investor protection, and performance in emerging markets. Journal of Corporate Finance, 10(5), 703-728.

Klomp, J., \& de Haan, J. (2009).Central bank independence and financial instability. Journal of Financial Stability, 5(4), 321-338.

Krejcie, R. V., \& Morgan, D. W. (1970). Determining sample size for research activities. Educational and psychological measurement, 30(3), 607-610.

Krishnamurti, C., Pensiero, D., \&Velayutham, E. (2016). Determinants of Defence Industry Corruption Risk: Firm-Level Empirical Evidence Using Transparency International's Anti-Corruption Index. The Singapore Economic Review, 1650005.

Lawal, B. (2012). Board dynamics and corporate performance: a review of the literature, and empirical Challenges. International Journal of Economics and Finance, 4(1), p22.

Lawal, B. (2016). Re: Duplication of corporate governance codes and the Dilemma of firms with dual regulatory jurisdictions. Corporate Governance: The International Journal of Business in Society, 16(3), 2-19. https://doi.org/10.1108/CG-08-2015-0115

Lorsch, J. W. and E. McIver (1989). Pawns or Potentates: The Reality of America's Corporate Boards. Harvard Business School Press, Boston, MA.

Mace, M. L., (1971). Directors: Myths and Reality, Cambridge, MA.: Harvard University Press

Mattingly, J. E. (2004). Stakeholder salience, structural development, and firm performance: Structural and performance correlate of sociopolitical stakeholder management strategies. Business \& Society, 43(1), 97-114.

Morf, L. S., Gloor, R., Haag, O., Haupt, M., Skutan, S., Di Lorenzo, F., \&Böni, D. (2013).Precious metals and rare earth elements in municipal solid waste-sources and fate in a Swiss incineration plant. Waste Management, 33(3), 634-644.

Mugesani, P. A. (2017). The role of Internal Corporate Social Responsibility Activities on Employees' commitment in Firms Listed in The Nairobi Stock Exchange. Strategic Journal of Business \& Change Management, 4(1).

Nasiru, A., Keat, O. Y., \& Bhatti, M. A. (2015).Moderating Role of the Perception of University Support on the Relationship between Perceived Effective Entrepreneurship Education and Perceived Creativity Disposition on Entrepreneurial Intention. International Journal of Management Research and Reviews, 5(5), 302.

Nath, S. D., Islam, S., \&Saha, A. K. (2015). Corporate Board Structure and Firm Performance: The Context of Pharmaceutical Industry in Bangladesh. International Journal of Economics and Finance, 7(7), p106.

Ngulumbu, O. M. (2013). Relationship Between Board Composition And Financial Performance Of Companies Listed At The Nairobi Securities Exchange. Unpublished, University of Nairobi.

Nicholson, G. J. and G.C. Kiel (2004). A framework for diagnosing board effectiveness, Corporate Governance: An International Review, 12(4), 442-460. 
Nielsen, S., \& Huse, M. (2010). The Contribution of Women on Boards of Directors : Going Beyond the Surface, 18(2), 136-148. https://doi.org/10.1111/j.1467-8683.2010.00784.X

Nordberg, D. (2011), Corporate Governance and the Board. In S. Idowu, and C. Louche, Theory and Practice of Corporate Social Responsibility Verlag Berlin Heidelberg: Springer, pp. 39-53.

Nuhu, M. and Ahmad, B. S. (2016).Investigating the issues and challenges of corporate governance in Nigerian, A Peer Reviewed International Journal of Asian Academic Research Associates, 3(12), 93-122. www.asianacademicresearch.org

Nuhu, M., \& Ahmad, B. S. (2017). Board composition and performance of listed firms in Nigeria: mediated and moderated model. Academic Journal of Business and Retail Management Research, 3(11), 25-38

Nuhu, M., \& Ahmad, B. S. (2017). Does corporate governance matter? Issues and challenges of the code of best practice in Nigerian.Academic Journal of Business and Retail Management Research, 3(11), $116-123$

Offe, C. (2009). Governance: an empty signifier? Constellations, 16 (4), 550-552.

Okpara, J.O., (2011)."Corporate governance in a developing economy: barriers, issues, and implications for firms", Corporate Governance: The International journal of business in society, Vol. 11 Iss 2 pp. $184-199$

Olusegun, A. H., Hasbullah, A., \&Nordin, N. (2014). Influence of Top Management Commitment, Stakeholder Pressure and Public Concern on Sustainable Environmental Manufacturing Practices in Malaysia: Data Screening and Preliminary Analysis. The International Journal of Business \& Management, 2(11), 189.

Ooi, Y. K. (2008). Inclination towards entrepreneurship among Malaysian university students in northern Peninsular Malaysia (Unpublished doctoral dissertation). Swinburne University of Technology, Melbourne, Australia

Padilla, A. (2002). Can agency theory justify the regulation of insider trading? Quarterly Journal of Austrian Economics, 5(1), 3-38.

Pérez, A., Pérez, A., López, C., López, C., García-De LosSalmones, M. D. M., \&García-De LosSalmones, M. D. M. (2017).An empirical exploration of the link between reporting to stakeholders and corporate social responsibility reputation in the Spanish context. Accounting, Auditing \& Accountability Journal, 30(3), 668-698.

Peterson, M. F., Arregle, J., \& Martin, X. (2012). Multilevel models in international business research, 451-457. https://doi.org/10.1057/jibs.2011.59

Ponemon, L., \& Michaelson, C. (2000). Ethics at the Core: Perspectives. Pricewaterhouse Coopers (2), 49.

Rampersad, H., \& Hussain, S. (2014). Authentic Governance Model, 5-10. https://doi.org/10.1007/978-3$\underline{319-03113-2}$

Rechner, P. L. and D. R. Dalton (1991). CEO duality and organizational performance: a longitudinal analysis, Strategic Management Journal, 12(2), 155-160.

Rettab, B., Brik, A. B., \&Mellahi, K. (2009). A study of management perceptions of the impact of corporate social responsibility on organizational performance in emerging economies: the case of Dubai. Journal of Business Ethics, 89(3), 371-390.

Ringle, C. M., Wende, S., \& Will, A. (2005). SmartPLS 2.0. Retrieved from http://www.smartpls.de

Robichau, R.W. (2011). The mosaic of governance: creating a picture with definitions, theories, and debates, The Policy Studies Journal, 39(S1), 113-130.

Salkind, N. J. (1997). Exploring Research ( $3^{\text {rd }}$ ed). Upper Saddle River, NJ; Prentice Hall

Samaduzzaman, M., Zaman, F., \&Quazi, Z. (2015).Literature Review on Corporate Governance Structure and Performance in Non-Financial Bangladesh Firms. Asian Journal of Finance \& Accounting, 7(1), 96-104.

Sanusi, L. S. (2012). Banking reform and its impact on the Nigerian economy. CBN Journal of Applied Statistics, 2(2), 115-122. 
Solomon, J. (2007). Corporate Governance and Accountability, West Sussex, England: John Wiley and Sons, Southern Gate.

Stevens, W. B., Hoeft, R. G., \&Mulvaney, R. L. (2005).The fate of nitrogen-15 in a long-term nitrogen rate study. Agronomy Journal, 97(4), 1046-1053.

Stiles, P. (2001). The impact of the board on strategy: an empirical examination, Journal of Management Studies, 38(5), 627-650.

Vafeas, N. \&Theodorou, E. (1998). "The Relationship between Board Structure and Firm Performance in the UK”, British Accounting Review, 30(4), 383-407.

Vance, Stanley C. (1964). Boards of Directors: Structure and Performance. Eugene, OR: University of Oregon Press.

Weisbach, M.S. (1988). Outside directors and CEO turnover, Journal of Financial Economics, 20:431461.

Yermack, D. (1996). Higher market valuation of companies with a small board of directors, Journal of Financial Economics, 40(2), 185-211.

Zahra, S. and J. Pearce (1989). Boards of directors and financial performance: a review and integrative model, Journal of Management, 15(2), 291-334.

Zehir, C., Çınar, F., \&Şengül, H. (2016). The role of Stakeholder Participation between Transparency and Qualitative and Quantitive Performance Relations: An Application at Hospital Managements. Procedia-Social and Behavioral Sciences, 229, 234-245. 